ZESZYTY NAUKOWE UNIWERSYTETU SZCZECIŃSKIEGO

NR 884

EKONOMICZNE PROBLEMY USŁUG NR 119

2015

DOI: 10.18276/epu.2015.119-02

\title{
Monika Rozmarynowska-Mrozek*
}

\section{THE DEVELOPMENT OF THE LNG-FUELLED FLEET AND THE LNG-BUNKERING INFRASTRUCTURE WITHIN THE BALTIC AND NORTH SEA REGION}

\begin{abstract}
In the recent years the growing interest in LNG-fuelled ships has been visible. The regulations concerning emission limits from ships' engines in SECA contained in MARPOL 73/78 Convention are the main driver of the development of this kind of vessels' propulsion. The boosted interest in LNG fuelled-ships in recent years, especially within the Baltic and the North Sea, which are included in SECA, has caused the increase in a number of initiatives concerning LNG bunkering facilities within these regions. The main aim of this article is to analyse the recent development in the field of the LNG-fuelled fleet and the LNG bunkering facilities within the Baltic and North Sea region.
\end{abstract}

Keywords: LNG-fuelled vessels, LNG-bunkering infrastructure, Baltic Sea Region, North Sea Region

\section{Introduction}

In the recent years the growing interest in the LNG-fuelled ships has been visible. The regulations concerning $\mathrm{SO}_{\mathrm{x}}$ emissions from ships' engines in SECA

* Monika Rozmarynowska-Mrozek, MScEng, Gdynia Maritime University, Faculty of Navigation, Department of Transport and Logistics, e-mail address: monroz@am.gdynia.pl. 
contained in Annex VI of IMO's MARPOL 73/78 Convention are the main driver of development of this kind of vessel's propulsion. According to the regulations of January 1st, 2015, ships are not supposed to use marine fuels with the sulphur content exceeding $0.1 \%$ by mass within SECA area in order to meet the regulations, ships may use marine gas oil (MGO), with the significantly lower content of sulphur than intermediate fuel oil (IFO), used before the regulations came into force. However, MGO is usually much more expensive than IFO. This have recently boosted the interest in alternative solutions to meet the new regulations. One of that solutions is LNG. LNG is regarded as clean fuel, it contains virtually no sulphur, hence $\mathrm{SO}_{\mathrm{x}}$ emissions from natural gas engines are reduced by close to $100 \%$. The particle emission is also reduced by close to $100 \%$. Moreover, burning LNG produces $85 \%-90 \%$ less $\mathrm{NO}_{\mathrm{x}}$ than the conventional fuel, and greenhouse gas emissions are reduced by $15-20 \%$ (Greener Shipping in the Baltic Sea 2010: 7). What is more, using LNG is regarded also as an economically more beneficial than using MGO, because LNG is usually cheaper than MGO (Matczak 2014:12856). The increased interest in LNG in the recent years has boosted the interest in LNG bunkering infrastructure and facilities within the Baltic and the North Sea. Only a few years ago there were no LNG-propelled vessels within Europe (apart from these operating within Norwegian waters), whilst today an increased development in this field is visible.

\section{Analysis of world LNG-fuelled fleet with the special focus on the Baltic and North Sea Region}

The history of LNG-powered ships (other than LNG carriers) began in 2000 when the first such vessel was put into operation by a Norwegian car/passenger ferry shipowner, Fjord1 (Rozmarynowska 2012: 745). From 2000 to 2010, 21 of such ships have been put into operation, and practically all of them operated only in the Norwegian waters. However, since 2010 this number has tripled (Fig. 1). Moreover, currently LNG-fuelled vessels sail not only in Norwegian waters anymore, but also in other parts of Europe as well as in Asia and Americas. 


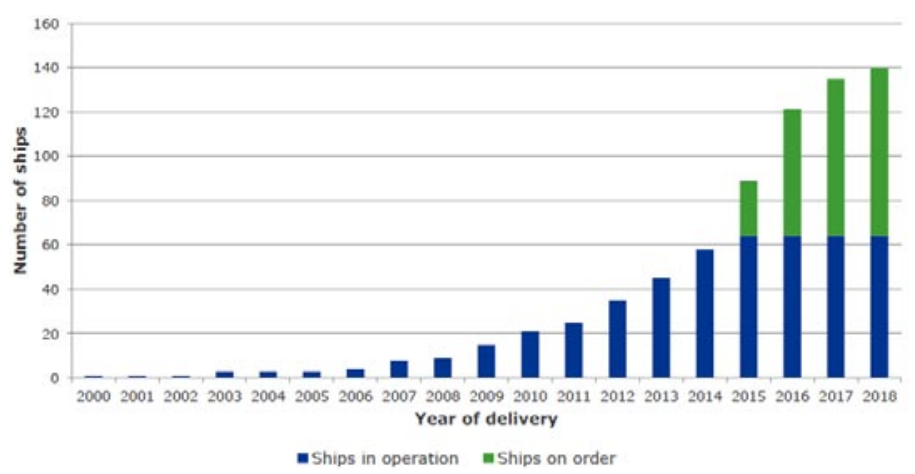

Figure 1. Development of LNG-fuelled fleet

Source: www.dnvgl.com/maritime/lng/ships.html.

As of July 2015, there were 65 LNG-fuelled ships in operation. Still, the majority of them (around 81\%) have been engaged in the Norwegian domestic traffic and represents mainly small ships such as car/passenger ferries and offshore ships (PSV - Platform Supply Vessel). As far as the Northern Europe (the North Sea and the Baltic Sea) is concerned, today, 7 LNG-fuelled ships operate in this region (Fig. 2).
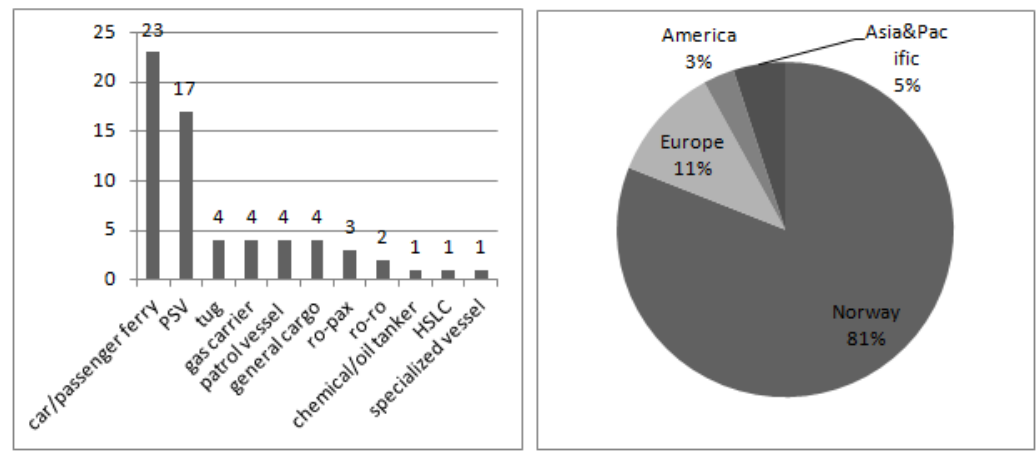

Figure 2. Number of LNG-fuelled vessels in service per vessel segment and region of operation (as of July 2015)

Source: Own elaboration on the basis of: www.dnvgl.com/maritime/lng/ships.html.

The first LNG-powered vessel that has been put into service within the Baltic Sea region and at the same time the first large po-pax vessel worldwide is MS Viking Grace owned by Viking Line, Finnish ferry operator. The ship started 
her operation in January 2013. The 57,000 GT ferry has been operating between Turku in Finland and Stockholm in Sweden. She has a length of 214 metres, a width of $31.8 \mathrm{~m}$ and is able to accommodate 2,800 passengers. The ferry is equipped with four Wärtsilä dual fuel (LNG/diesel) engines, of a combined power of 30,400 kW. Viking Grace consumes about 60 tonnes of LNG per day and about 22,500 tonnes per year. The ferry has cost around EUR 240 million, of which amount EUR 28 million is owing to a Finnish Government subsidy (ship-technology.com, 2015).

Another two large LNG fuelled ferries have been put into operation by the Fjord Line. The first vessel, MS Stavangerfjord, entered into service in July 2013, while the second - MS Bergensfjord - in March 2014. The 25,000 GT ferries are $170 \mathrm{~m}$ long, $27.5 \mathrm{~m}$ wide, and are able to accommodate 1,500 passengers (fjordline.com, 2015). These vessels are the first and largest ferries in the world to sail with a "single LNG engine", which means that they use solely LNG fuel. Both ferries have been engaged into servicing the Norway - Denmark route (specifically, the Hirtshals - Stavanger - Bergen route).

One of the LNG-fuelled ferries to have been put into operation lately in the Northen Europe (March 2015) is MF Samsø. The ferry has been ordered by the Samsø Municipality (Demark) and bound for a domestic Danish route, between the mainland (Jutland) Hou and the island Samsø. The vessel is $100 \mathrm{~m}$ long and able to carry 60 personal cars, or 16 lorries and 600 passengers (rmdc. rh.pl, 2015).

Among the other three vessels that operate within the Northern Europe and use LNG as fuel is the petrol vessel operated on Finnish waters by the Finnish Border Guard from 2014 and two gas carriers operated by the ship-owner Anthony Veder. LNG-fuelled gas carriers have been in operation since 2014 and carry Liquefied Ethylene Gas (LEG) from SABIC's Wilton facility on Teesside (UK) to manufacturing plants in the north-western Europe and Scandinavia (anthonyveder.com, 2015). These are the first LNG-fuelled ships operating within the western part of Northern Europe.

There are more and more orders for LNG-fuelled ships. As of July 2015, there were 79 LNG powered vessels on order worldwide. Around 35 (45\%) of these vessels have been are designed for the European market (mostly for the North European market). A large number of orders also come from Americas ( $34 \%$ of the overall order book) and Norway (15\%). It can be indicated that among the ordered ships, the largest part constitutes four types of vessels: containerships 
car/passenger ferries, gas carriers (other than LNG), and PSV. Together, these types of ships account for over $60 \%$ of the total world orderbook (Fig. 3).
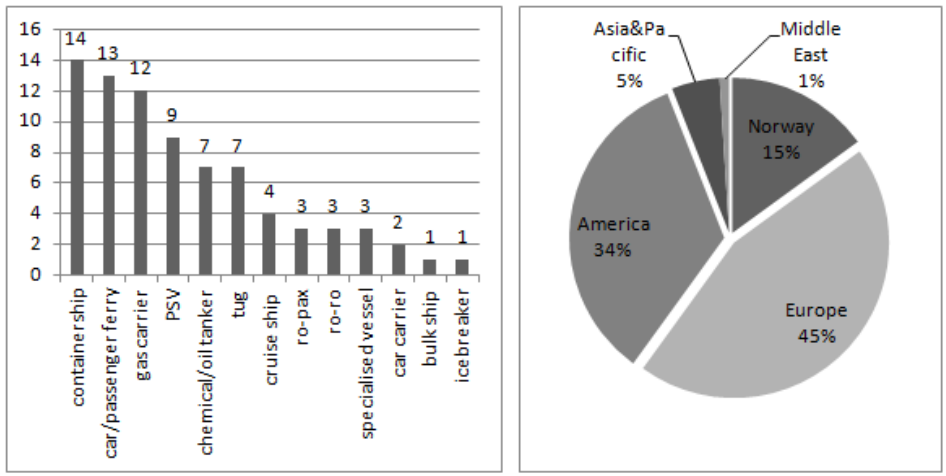

Figure 3. Number of LNG-fuelled vessels on order per vessel segment and region of operation (as of July 2015)

Source: own elaboration on the basis of: www.dnvgl.com/maritime/lng/ships.html.

Most of the ordered LNG powered container ships (8) are dedicated for intra-European routes, and the rest (6) - for intra-North American routes. Among the ships intended for servicing intra-European feeder trades there are, for example, two container ships ordered by the Croatian Brodosplit, falling within the capacity range from 1,300 to $1,500 \mathrm{TEU}$. It is expected that these ships will enter into service in 2015 thereby becoming the first container vessels fuelled by LNG. Another four ships dedicated for the European market are ordered by the German shipowner GNS Shipping/Nordic Hamburg. The vessels will later be chartered by the Finnish operator Containerships. The $170 \mathrm{~m}$ long ships of the capacity of 1,368 TEU will be built by the Yangzhou Guoyu Shipbuilding Co. (marinelog. com, 2015). Two ships are scheduled for delivery in the course of 2016 and the other two - in 2017. Containerships have also ordered another two LNG powered container vessels whose deliveries are scheduled for 2018. All of these ships will be probably engaged in the service of Northern European context.

Among the container ships designed for the American market are: two container ships ordered by the TOTE Shipholdings intended for the US - Puerto Rico route and scheduled to start operating in 2015 as well as the four ships scheduled for delivery in 2017 and 2018 ordered by the Crowley Maritime Corporation and 
Matson Navigation Company. These ships are dedicated for the North America routes.

In the case of car/passenger ferries, 5 out of 13 orders are intended for European routes, and the rest for Canadian routes. Among these five ferries there are two ships ordered by the German ferry owner AG Ems, and scheduled to be delivered in 2015. The first order is a conversion project. The existing ship, Ostfriesland is being retrofitted with the Wärtsilä's 20DF engines and an LNGPac. The ship is being rebuilt and its length will increase from $78.7 \mathrm{~m}$ to $92.7 \mathrm{~m}$ to accommodate 1,200 passengers. The second ship, Helgoland, is a newbuild. The cost of the new vessels is estimated at EUR 31 million (lngworldnews.com, 2015). The ships are designed for servicing domestic German routes.

The investment in an LNG-fuelled ferry is also planned by the Tallinn ferry operator . In February 2015 the AS Tallink Grupp and the Meyer Turku Oy signed a contract for the construction of an LNG-powered fast ferry for the TallinnHelsinki route shuttle operations. The ship, with a gross tonnage of 49,000 , will be about 212 metres in length with a passenger capacity of 2,800 . The fast ferry will cost around EUR 230 million and will be delivered at the beginning of 2017 (meyerturku.fi, 2015). The remaining two ferries, designed for European routes, have been ordered by the Boreal Transport Nord AS. They are scheduled to be put into operation in 2016 on the Norwegian waters.

As far as LNG-fuelled gas carriers are concerned, around 8 out of 12 ordered vessels of this type is bound for the European routes. The ships are scheduled to enter into service in 2015 and 2016.

Next to container vessels, car/passenger ferries, and gas carriers, there will also be many other types of ships fuelled by LNG that in future will be operating on the European waters (inter alia: PSV, tugs, ro-ro ships, ro-pax ships, car carriers incebreaker).

One out of the three ordered ro-ro ships has been designed for the Norwegian market and the others - for the American and Australian markets. The ro-ro ship dedicated for the Norwegian market has been ordered by the Nor Lines AS, a Norwegian logistics and shipping company. The 5,000 dwt vessel has been built by Tsuji Heavy Industries (Jiangsu) in China and scheduled for delivery in 2015. This is the second ship of its kind ordered by the ship operator; the first one was delivered in February 2015.

All of the three ordered ro-pax ships will be operated within the European waters. Two of the ro-pax ship have been ordered by Rederi AB Gotland. One 
of them will be chartered to the Destination Gotland, and put on its Nynäshamn -Visby line, replacing the two smaller and older high-speed crafts, The investment (approximately EUR 160 million) has been placed in the Chinese GSI shipyard. The new 1,650-passenger capacity vessel is scheduled for delivery in the first half of 2017. The delivery of the second ship is scheduled for 2018, however, it has not been decided yet which connection she will serve (baltictransportjournal. com, 2015).

Another LNG-fuelled ro-pax ship has also been ordered by the Spanish operator Baleŕria. The LNG propulsion will be installed on-board the existing ferry Abel Matutes which operates between Barcelona and Palma de Mallorca (lngindustry.com 2015).

The two ordered car carriers will be operated by the United European Car Carriers (UECC) and intended for Baltic market. The vessels will be $181 \mathrm{~m}$ long with a $30 \mathrm{~m}$ beam. The ships will be able to take on-board approximately 3,800 standard-sized cars across 10 decks. Both vessels will be dual-fuel, capable of operating on LNG or IFO/MGO. Deliveries of both new units are scheduled to take place in the second half of 2016 (uecc.com 2015).

DNV GL forecasts that there will be more and more orders for LNG-powered ships during the next several years. According to the DNV survey (Shipping 2020, 2012), in 2020, there will be approximately 1,000 LNG-powered vessels worldwide. Offshore vessels and ships operating in regular shipping (ferries, ro-ro ships, and container vessels) will dominate the future LNG-fuelled fleet and may account for about $60 \%$ of that fleet. In Europe, there will be about 400 of such ships. Offshore ships and passenger ships will constitute the largest group. However, the forecasts prepared three years ago were probably too optimistic. Analysing the number of LNG-fuelled ships operating today and ordered, it can be indicated that the development of such fleet will be not so rapid and a future number of ships powered by LNG may be much lower than predicted by DNV. There are many factors influencing ship owners' decisions as to whether to invest in LNG. Among them there are, inter alia: type and age of the ship, its area of operation, value of the cargo (potential loss of cargo space), global, regional and local availability of the LNG, price of LNG and its relation to the price of other fuels, cost of LNG installation and its relation to the cost of other solutions (e.g. scrubbers). 


\section{LNG fuel prices}

Without a doubt, the LNG-powered ships investment costs comprises one of the main factors taken into account when deciding whether to invest in LNG or not. Generally, a new LNG-powered ship is approximately $20 \%$ more expensive than a ship with the traditional engine. However, another, equally important issue is the LNG fuel price. The level of this price, particularly its relation to prices of typical bunker fuels, can to the large extent influence the level of ships' operational costs. LNG usually is cheaper than MGO; a reason why, in the long term, LNG may turn out to be economically more beneficial than MGO.

\section{LNG prices at global markets}

In order to build some overview on the LNG price issue, a short analysis of LNG prices in major global markets will be carried out. As it can be seen from Figure 4, LNG prices vary widely by region. The reasons for these differences are that the international gas market is fragmented by legal and regulatory requirements, it lacks international transparency and benchmarks, and there are different approaches to contracting. Generally, there are three major pricing systems in the current LNG contracts worldwide:

- oil-indexed contract used primarily in Japan, Korea, Taiwan and China,

- oil and oil products-indexed contracts used primarily in Europe,

- market-indexed contracts (price driven by supply and demand) used in the USA.
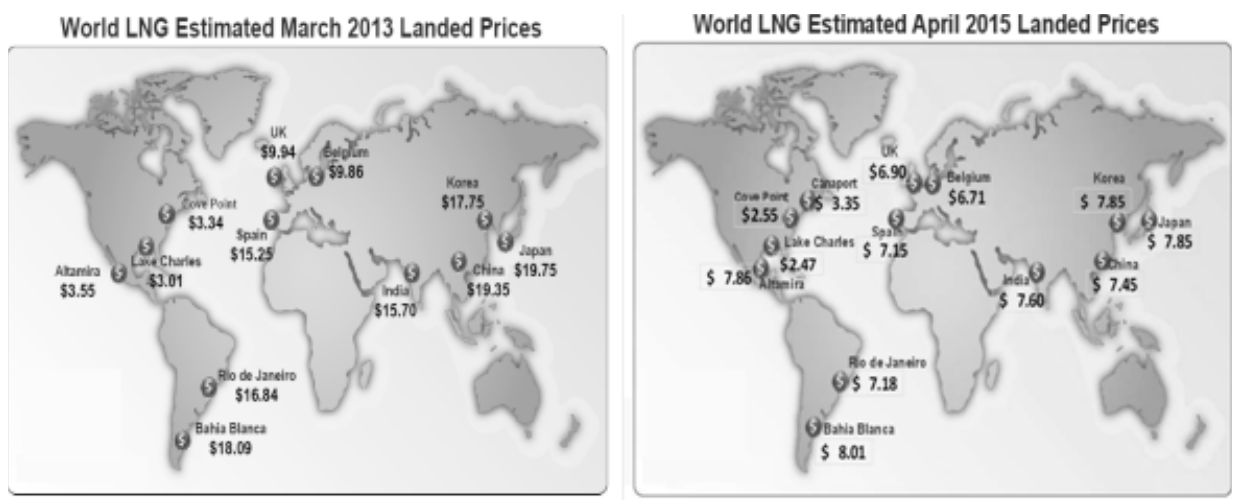

Figure 4. World LNG prices in March 2013 and in April 2015

Source: www.ferc.gov/market-oversight/othr-mkts/lng/2013/02-2013-othr-lng-archive.pdf; www.ferc.gov/market-oversight/othr-mkts/lng/ngas-ovr-lng-wld-pr-est.pdf. 


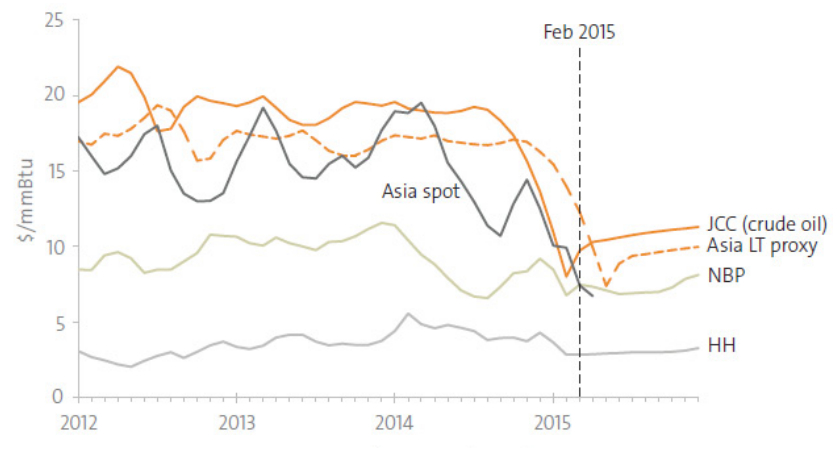

Figure 5. Gas and LNG prices

Source: http:/www.bg-group.com/480/about-us/lng/global-lng-market-outlook-2014-15/.

The highest prices of LNG are observed in the Asian Pacific market, currently dominated by long-term contracts indexed to oil prices. As a result, when oil prices are high, so are LNG prices (Fig. 5). In March 2013 Asian customers paid between USD 15 to 20 per mmBtu of LNG. The dramatic drop in oil prices across the globe due to a weaker demand and increased supply (which started in the mid - 2014), has had its reflection in the decrease of LNG prices. In April 2015, LNG prices on Asian Pacific market were at around USD 7-8 per mmBtu. The lowest prices for LNG have always been paid in the USA, where the gas price is driven by supply and demand and further set by the gas-to-gas competition. In March 2013 in the USA one mmBtu cost around USD 3-3.5, while in April 2015 the price ranged between USD 2.5-3.5 per mmBtu. In Europe where the LNG gas price mechanism is linked to the crude oil and oil products prices, the LNG price oscillates between the USA and Asian prices. In March 2013 the price for mmBtu of LNG oscillated at around 15 USD (Spain) and 10 USD (the UK and Belgium), whilst two years later, in April 2015, it was around USD 7 per mmBtu, which means that the LNG price in Europe was comparable with the Asian prices.

\section{LNG fuel prices}

As a bunker fuel, LNG has already been available in some locales within the North and the Baltic Seas. Currently, there is a possibility of delivering LNG to maritime clients within the southern Norway, southern Sweden, southern Finland and in all Denmark by Skangass. Bunkering of LNG-powered sea-going vessels 
is also possible in the port of Zeebrugge and Rotterdam by the Dutch LNG supplier, LNG Europe. In some places within Europe there is also a possibility of bunkering inland-going vessels, while a possibility of bunkering sea-going vessels is being investigated (for example: Amsterdam, Antwerp). However, LNG bunkering market is still a niche market. As the ship fuel, LNG is sold on a small scale to a few customers from shipping sectors, each ship owner is treated individually and the prices are settled individually and according to the customer's needs. Today, two main LNG fuel pricing mechanism exist:

1. LNG fuel price index to Hub prices.

2. LNG fuel price index to MGO prices.

For example, the Skangass is able to index LNG price to HFO prices, MGO prices or Gas Hub prices, the choice depends on clients' preferences. Generally, after discussions with client from maritime sector, it usually ends up with gas index price. The Skangass offers both spot supplies and long term contracts. Spot supplies are popular among PSV vessels operators in Norway. In agreements with these operators there are no fixed volumes, and the company delivers LNG to vessels when they need it. The other company that is able to deliver LNG to maritime clients, LNG Europe, quotes LNG at Zeebrugge hub. They mainly focus on long term relations but are also open to other forms of cooperation.

In the first half of 2014 the price of LNG index to MGO was generally from $30 \%$ to $80 \%$ higher than the LNG index to Hub prices. The situation began to change in the second half of 2014, when prices of MGO began drifting down significantly, due to the drop in oil prices across the globe. In consequence, the price of LNG index to MGO and the price of LNG index to Hub became comparable and in some cases it was possible to get a lower price indexed at MGO rather than at Gas Hub (Fig. 6). The lower prices of MGO made that LNG index on Hub become less competitive than it was before the decrease of prices of bunker fuels.

When LNG is indexed to MGO, it means that some discount to the price of MGO is made, to compete with LNG. When LNG is indexed to hub price, it means that the whole price includes the LNG price at hub and other additional cost connected to the LNG fuel supply chain, such as the cost of storage or transhipment to local port facilities and further to the end user. Generally, the more steps the LNG fuel supply chain includes, the higher the final price is. Hence, it is indicated that the lowest price is able to be offered by import terminals or large liquefaction plants with access to cheap gas. The final price depends also on the 
LNG bunkering solution (ship to ship, track to ship, onshore installation). Different solutions generate different costs affecting the final LNG fuel price. Moreover, future LNG fuel price levels depend on a series of different, highly uncertain factors. Among these factors the most important are: the level of demand, level of supply, oil-gas price relation, development of alternative fuels, geopolitical developments. Additionally, the level of final price of LNG for shipping sector is depended on the type of LNG supply chain (whether LNG for bunker purpose is supplied from an LNG import terminal or from the land side) and LNG bunkering solution (see Chapter 3).

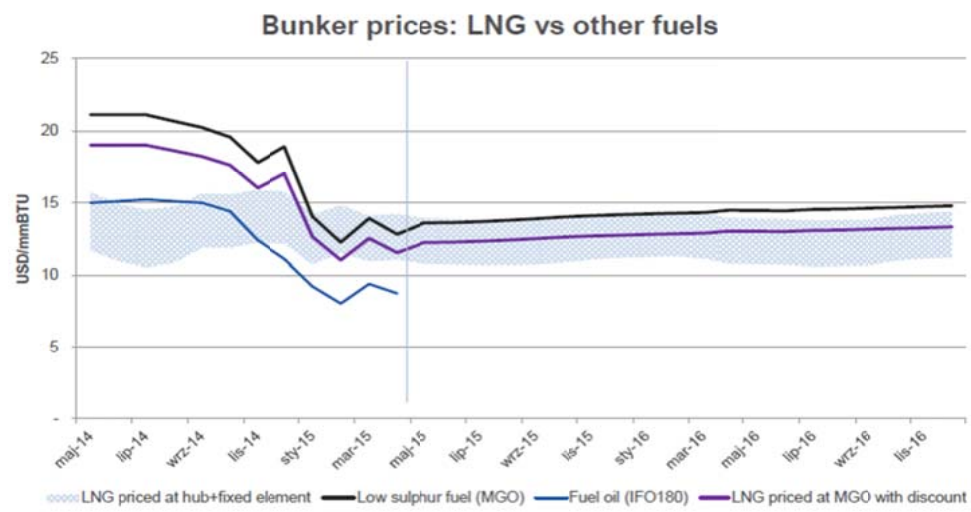

Figure 6. Bunker prices: LNG vs other fuels

Source: S. Mazaic, Fuel prices and impact on LNG prices, Sund Energy, LNG in BSR Project II Seminar Materials, 2015.

3. LNG bunkering infrastructure - the existing and the planned - in the Baltic and North Sea regions

\section{Existing bunkering infrastructure in the Baltic and North Sea ports}

Today the following three types of LNG bunkering solutions are available in some locations within the Baltic and North Sea region:

- tank truck-to-ship bunkering,

- ship-to-ship bunkering (at quay or at sea),

- terminal to ship bunkering. 
For each individual port a different solution can be the most suitable. Generally, many factors should be taken into account during the process of analyzing the best solution for a particular port, among which there are: traffic intensity, frequency, bunkering volumes, physical limitations, logistical issues.

The first option should be considered as the most flexible solution in the spatial means but similarly an important limitations of technology could be defined. The distribution of LNG by the trucks allows to reach any seaports berth and provide the fuel to LNG-propelled vessels. The area of this distributor's activity is practically not limited. On the other hand, the main restrictions concerning the truck-to-ship technology is the limitation of LNG tank capacity (typically $40-80 \mathrm{~m}^{3}$ ). This solution is also characterised by the relatively low efficiency and long duration of bunkering operations. For example, the bunkering operation from one tank truck with a capacity of about $55 \mathrm{~m}^{3}$ generally takes about 1.5 hours, which means that the filling of two ships' tanks with the capacity of $120 \mathrm{~m}^{3}$ can take approximately 6.5 hours (MAGALOG 2008: 34). Bering these restrictions in mind, the solution is suitable only for small vessels that are equipped with tanks up to $200 \mathrm{~m}^{3}$, or for vessels whose turnaround time is long enough for bunkering activities (North European LNG Infrastructure Project 2012: 12).

The ship-to-ship bunkering can be performed alongside the quay, but it is also possible to bunker at anchor or, in some cases, even during the voyage. This solution is flexible - it is possible that bunkering takes place at a different location in the port or even at sea. In the case of ship-to-ship bunkering, the capacity of the tank may be much higher than in the case of road truck, it can range from approximately several $100 \mathrm{~m}^{3}$ to $10,000 \mathrm{~m}^{3}$. The crucial advantages of the ship-to-ship bunkering process is a high efficiency of the bunkering process itself (approx. 3,000 litres per hour). Due to technical and economic reasons, this type of a solution is most suitable for vessels equipped with tanks whose capacity amounts to no less than $100 \mathrm{~m}^{3}$.

In the third case, bunkering operations take place at the quay from the fixed onshore installations. The main advantage of this solution is the short time of the bunkering operation (the refuelling rates can be high). It is particularly suitable for vessels operating in the high frequency liner shipping with short turnaround time. These solutions require an investment in onshore LNG storage tanks, their size may vary from very small $\left(20 \mathrm{~m}^{3}\right)$ to very large $\left(100,000 \mathrm{~m}^{3}\right)$, depending on potential demand (North European LNG Infrastructure Project 2012: 82). Bearing that in mind, the important issue concerning this solution is the availability 
of space for LNG storage tanks in a close proximity of the quay where bunkering operations are performed. Installing tanks too far from the quay may be technically not possible or not cost-effective, due to the long pipeline that must connect storage tanks with facilities at the quay.

A few years ago, within Europe, LNG, as the ship fuel, was available practically only in Norway. Norway, as a pioneer in the field of LNG-powered ships, has also the greatest experience in the field of LNG bunkering facility. Today bunkering of vessels propelled by LNG is available in many locations in Norway. Two solutions are, mainly, used to deliver LNG to ships: the truck-to-ship bunkering and the bunkering via pipeline from onshore LNG small scale storage tanks. The second option is currently available at several locations in Norway: at Florø and Coast Centre Base (CCB) Ågotnes where offshore supply vessels are bunkered, at Halhjem Terminal in Bergen where LNG powered ferries are bunkered and at Risavika, Øra terminal in Fredrikstad and Snurrevarden. Today, LNG, as a fuel, is available in other North European countries. Some examples of the existing facilities and possibilities of bunkering LNG-fuelled vessels within the Baltic and North Sea region are presented below.

\section{Port of Stockholm (Sweden)}

The port of Stockholm is the first port within the Baltic Sea Region where LNG as a fuel started to be available for ships. The port started to perform the LNG bunkering operation in January 2013 when the ship Viking Grace was put into service. Initially, Viking Grace was refuelled from a tank truck. However, at the beginning of April 2013 the ship-to-ship bunkering started at the regular basis. The first vessel for bunkering purposes, Seagas, was formerly a passenger ferry vessel, however, is has been converted into a LNG bunker ship. The project was carried out by AGA AB in the port of Stockholm. The Bunker vessel is based in the port of Stockholm. The project has cost EUR 1.3 million, of which amount EUR 261 thou. came from the European Union's TEN-T program (bairdmaritime.com 2015). The fuelling process takes just under an hour. The natural gas used as fuel for M/S Viking Grace comes from the AGA's LNG-terminal in LNG terminal in Nynäshamn. 


\section{Port of Helsinki (Finland)}

In this day and age in the port of Helsinki the tank-to-ship bunkering is possible. Currently, the Finnish Border Guard's LNG-fuelled offshore patrol vessel Turva is bunker in Helsinki on regular basis. The vessel operates in the Gulf of Finland and, apart from Helsinki ,she can replenish fuel at various Gulf of Finland ports, such as Hanko, Hamina, Vuosaari, Turku, Pori, and Raahe where LNG can be delivered by the Skangass by road tank trucks from the company's own production plant in Porvoo.

\section{Port of Hirsthals (Denmark)}

The LNG bunkering facility in Hirsthals has been put into operation in the mid-2015. The project in Hirtshals was cofinanced by EU's TEN-T Programme (EU). It covered the development of a 200 tonnes $/ 500 \mathrm{~m}^{3} \mathrm{LNG}$ storage tank and a bunkering facility. The new facilities provide LNG for two LNG-fuelled vessels of the Fiord Line and they are also opened for other ship operators (ngvglobal. com 2015).

\section{LNG bunkering possibilities in North Sea ports}

It can be indicated that North Sea ports are more experienced in regard to bunkering inland ships rather than to sea going vessels. As a fuel for inland vessels, LNG is available already in Rotterdam, Antwerp, and Amsterdam, and is delivered by road trucks. However, all of these ports investigate the possibility of bunkering sea-going vessels or even have an ongoing investments in these field. The first port in this part of Europe that performed the bunkering operation of a seagoing vessel was Zeebrugge. The operation took place in February 2014. LNG was then supplied to the world's first LNG-powered tug. Fuel was delivered via the LNG Europe by a tank truck.

On the west part of the North Sea bunkering of ships fuelled by LNG is possible from May 2015 in Teesport in the United Kingdom. Currently two SABIC-chartered gas carriers, Coral Star and Coral Sticho, are bunkered there (sabic.com 2015). 


\section{Planned and considered investments in bunkering infrastructure within} the Baltic and the North Sea regions

Many ports within the Baltic and North Sea region plan or consider investments related to bunkering LNG-fuelled ships. Some plans are more advanced, some less. It is worth emphasizing that in many cases planned infrastructure is not limited to the bunkering purposes but also other users such as land transport users or industry and gas system are discussed as prospective clients. Generally, it would be more beneficial to create synergies between various users in one particular area rather than concentrate on one market segment with a wider regional focus. This would be beneficial for both LNG terminal operators (the optimisation of operational cost) and users (the improvement of LNG pricing). Below, there is a description of small scale LNG initiatives in ports within the Baltic and North Sea region. The highest number of such initiatives is concentrated in Sweden and Finland.

In Sweden one of the LNG facilities is developed in Gothenburg. It is a joint initiative of the Royal Vopak, and the Swedegas. The LNG terminal in Gothenburg is also part of a project being run together with the port of Rotterdam and the Gasunie in an effort to create an efficient LNG infrastructure between Sweden and the Netherlands. The terminal will supply LNG to industry and shipping and be open to all parties interested in the Swedish market. The planned storage capacity of the full developed terminal is $30,000 \mathrm{~m}^{3}$. The facility is planned to be put into operation in 2015.

A small scale LNG terminal is planned to be built also in Gavle by the Skangass. The construction works are planned to start in 2015 and the terminal is scheduled to be ready in 2017 . The terminal will be equipped with one storage tank of $30,000 \mathrm{~m}^{3}$.

Among other Swedish ports that consider or plan to develop LNG bunkering infrastructure are: Helsingborg, Trelleborg and Sundsvall. All of these ports take part in LNG in the Baltic Sea Ports II Project cofinanced by EU.

Within the next few years several small scale LNG import terminals are going to be built in Finland, for instance in Turku, Tornio, Pori, Rauma and HaminaKotka. It is planned that all terminals will supply LNG to industry, maritime transport and road transport. The terminal in Turku is a joint initiative of the Gasum and the port of Turku, the planned capacity of storage tanks is around $30,000 \mathrm{~m}^{3}$. The terminal in Tornio will be built by the Manga LNG Oy and 
equipped with the LNG storage capacity of $50,000 \mathrm{~m}^{3}$. It is scheduled to be put into operation in 2017. The terminal in Pori will be built by the Skangass Oy. The Pori terminal will have the LNG storage capacity of $30,000 \mathrm{~m}^{3}$. It is scheduled to be ready in the autumn of 2016. Rauma's terminal is going to be built by Oy Aga $\mathrm{Ab}$. The combined storage capacity of the Rauma terminal's eight LNG tanks will be $10,000 \mathrm{~m}^{3}$. The work on this terminal is set for completion in the early 2017. The terminal in HaminaKotka will be built by the Haminan Energia. The Haminan Energia LNG terminal, scheduled to be ready in 2018, will be equipped with one LNG tank of $30,000 \mathrm{~m}^{3}$ and the facilities related to receiving, unloading, storing and delivering LNG (tem.fi 2015).

Among other Baltic ports that plan on or consider the LNG infrastructure are, inter alia: the port of Tallinn (Estonia), the port of Rostock (Germany), the port of Klaipeda (Lithuania), the port of Aarhus (Denmark), the ports of Copenhagen - Malmo (Denmark/Sweden).

Within North Sea region, the main investments in LNG bunkering facilities concentrates in Rotterdam and Zeebrugge. For example in Rotterdam a specialised LNG bunkering vessel to deliver fuel to LNG fuelled vessels will operate in near future. The new vessel will be based at the port of Rotterdam but it will be able to bunker customers at other locations. The vessel will load from the new LNG break bulk terminal and jetty that is under construction at the Gas Access to Europe (Gate) terminal (portofrotterdam.com 2015). Ship to ship bunkering will be also available in Zeebrugge. Bunkering vessel ordered in Korean shipyard Hanjin Heavy Industries is expected to be in delivered in 2016. Vessel will load LNG at the Fluxys LNG terminal and will be based at Zeebrugge but she will be able to deliver fuel to LNG fuelled in other locations within North Sea and the Baltic Sea (nyk.com 2015).

\section{Summary}

The development of LNG-fuelled fleet has been accelerated especially after 2010. Since 2010, the number of vessels that use LNG as a fuel has tripled. Still, around $81 \%$ of them only sail in Norwegian waters. However, more and more of this kind of ships are built for other northern European regions. Today, 7 LNG-fuelled ships operate within the Baltic and the North Sea and about 35 are on order and scheduled to be put into operation in 2015-2018. It is also expected 
that there will be even more orders during the next years. Two of the main factors which have to be taken into account when deciding whether to invest in LNG or not are: the costs of investment in LNG-powered ships and price of LNG fuel. There is still a question mark hanging over the second issue. Although, as a fuel for ships, LNG is available in some localisations within the North Sea and the Baltic Sea already, no one can give a simple answer to how the price will get shaped in the future. Still, the LNG bunkering market is a niche market. As ship fuel, LNG is sold on a small scale to a few customers from shipping sectors, each ship owner is treated individually and the prices are settled individually and according to the customer's needs. Today three types of LNG bunkering solutions are available: tank truck-to-ship bunkering, ship-to-ship bunkering (at quay or at sea), terminal-to-ship bunkering. Generally, the first investments in ports in bunkering facilities were associated with the ship owners' particular investments in LNG-powered ships. Currently, within the northern Europe (excluding Norway), LNG bunkering operations are preformed, for example, in Stockholm, Hirtshals, Helsinki, Zeebrugge, Teesport. However, many other ports develop or plan to develop LNG bunkering facilities. One part of this initiative is associated with particular investments of ship owners, another results from the willingness to be prepared for potential future demand. The highest number of initiatives concerning LNG infrastructure for bunkering purposes is concentrated in Sweden and Finland, however, also ports in other countries (e.g. Germany, Estonia, Denmark, Lithuania, Netherlands) are developing or planning to develop such infrastructure.

\section{References}

Greener Shipping in the Baltic Sea, DNV, June 2010.

Maritime Gas Fuel Logistics. Developing LNG as a Clean Fuel for Ships in the Baltic and North Seas, Report from the MAGALOG Project, 2008.

Matczak M., LNG jako tadunek oraz źródlo napędu dla statków morskich, "Logistyka" 2014, No. 6.

Mazaic S., Fuel Prices and Impact on LNG Prices, Sund Energy, LNG in BSR Project II seminar materials, 2015.

North European LNG Infrastructure Project, A Feasibility Study for an LNG Filling Station Infrastructure and Test of Recommendations, Danish Maritime Authority, Copenhagen, 2012. 
Rozmarynowska M., LNG jako alternatywne paliwo dla statków - aspekty techniczne, ekologiczne, ekonomiczne i regulacyjne, "Logistyka" 2012, No. 5.

Shipping 2020, DNV Report, 2012.

http://rmdc.rh.pl/rmdc-2872-samso-passenger-car-ferry, 2015.

www.anthonyveder.com/home/press-release/, 2015.

www.bairdmaritime.com/index.php?option=com_content\&view=article\&id=14032:seagas-heralds-new-lng-bunkering-era\&catid=114:workboats\&Itemid=209, 2015.

www.baltictransportjournal.com/lng/another-dual-fuel-ferry-for-destination-gotland,2176.html, 2015.

www.bg-group.com/480/about-us/lng/global-lng-market-outlook-2014-15/, 2015.

www.ferc.gov/market-oversight/othr-mkts/lng/2013/02-2013-othr-lng-archive.pdf, 2015.

www.ferc.gov/market-oversight/othr-mkts/lng/ngas-ovr-lng-wld-pr-est.pdf, 2015.

www.fjordline.com/Our-ships/MS-Stavangerfjord/Ship-facts/Facts/, 2015.

www.lngindustry.com/small-scale-lng/20022015/Rolls-Royce-GNF-in-LNG-engineagreement-289/, 2015.

www.lngworldnews.com/delivery-of-helgoland-lng-ferry-delayed/, 2015.

www.marinelog.com/index.php?option=com_k2\&view=item\&id=6697:containershipsoy-opts-for-lng-for-two-newbuilds\&Itemid=231, 2015.

www.meyerturku.fi/en/meyerturku_com/media/press_releases/press_and_media.jsp, 2015.

www.ngvglobal.com/blog/denmarks-first-lng-bunkering-facility-ready-for-fjord-line$0703,2015$.

www.nyk.com/english/release/3132/003357.html, 2015.

www.sabic.com/europe/en/news-and-media/news/2015/europe/20150727-Shell-announcement, 2015.

www.ship-technology.com/projects/viking-grace-ferry-finland/, 2015.

www.uecc.com/Fleet/New_Vessels.aspx, 2015.

www.dnvgl.com/maritime/lng/ships.html, 2015.

www.portofrotterdam.com/en/news-and-press-releases/gate-terminal-starts-construction-of-lng-break bulk-facility-at-the-port-of, 2015.

www.tem.fi/en/energy/press_releases_energy?89521_m=116057, 2015.

www.tem.fi/en/energy/press_releases_energy?89521_m=116897, 2015. 


\title{
ROZWÓJ FLOTY ZASILANEJ LNG \\ ORAZ INFRASTRUKTURY DO BUNKROWANIA PALIWA LNG \\ W REGIONIE MORZA BAŁTYCKIEGO I MORZA PÓŁNOCNEGO
}

\begin{abstract}
Streszczenie
W ostatnich latach obserwuje się coraz większe zainteresowanie statkami napędzanymi paliwem LNG. Głównym czynnikiem, który wpłynął na rozwój tego typu napędu są regulacje zawarte w konwencji MARPOL 73/78 dotyczące ograniczenia szkodliwych emisji z silników statkowych w regionie SECA. Zwiększone zainteresowanie statkami zasilanymi LNG, obserwowane zwłaszcza w regionie Morza Bałtyckiego i Morza Północnego, które należą do strefy SECA, przyczyniło się także do zwiększenia inicjatyw dotyczących infrastruktury do bunkrowania paliwa LNG. Głównym celem artykułu jest analiza rozwoju floty napędzanej LNG oraz infrastruktury do bunkrowania tego typu statków w regionie Morza Bałtyckiego i Morza Północnego.
\end{abstract}

Słowa kluczowe: statki zasilane LNG, infrastruktura do bunkrowania paliwa LNG, region Morza Bałtyckiego, region Morza Północnego 
